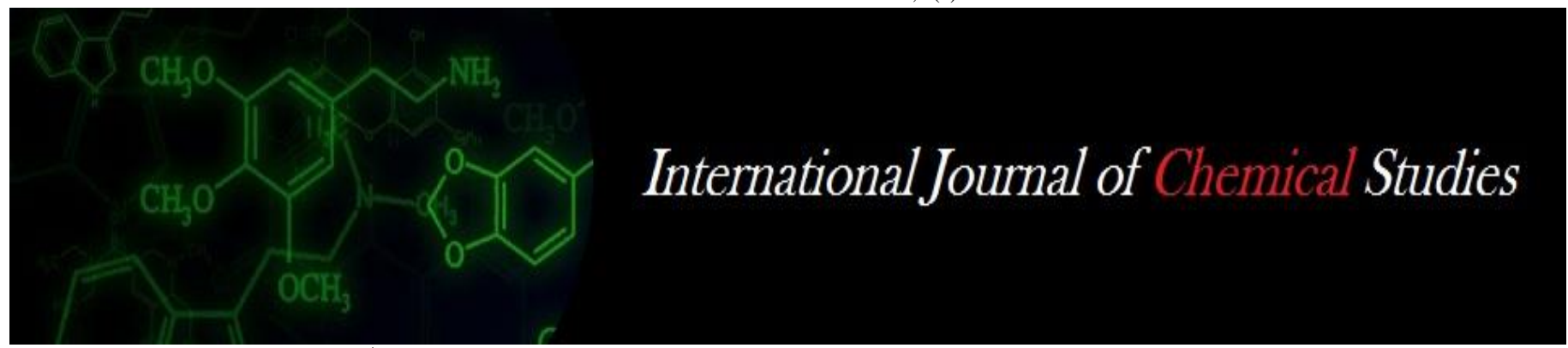

P-ISSN: 2349-8528

E-ISSN: 2321-4902

www.chemijournal.com

IJCS 2020; 8(2): 2419-2425

(C) 2020 IJCS

Received: 07-01-2020

Accepted: 09-02-2020

Praveen Kumar Patle

Department of Food Science and

Technology, Jawaharlal Nehru

Krishi Vishwa Vidhyalaya

Jabalpur, Maharashtra, India

\section{SS Shukla}

Department of Food Science and

Technology, Jawaharlal Nehru

Krishi Vishwa Vidhyalaya

Jabalpur, Maharashtra, India

\section{Ankit Bharti}

Department of Food Science and Technology, Jawaharlal Nehru Krishi Vishwa Vidhyalaya Jabalpur, Maharashtra, India

\section{GK Rana}

Department of Food Science and Technology, Jawaharlal Nehru Krishi Vishwa Vidhyalaya Jabalpur, Maharashtra, India
Corresponding Author: Praveen Kumar Patle

Department of Food Science and Technology, Jawaharlal Nehru Krishi Vishwa Vidhyalaya Jabalpur, Maharashtra, India

\section{Evaluation of different varieties of paddy for production of flaked rice}

\author{
Praveen Kumar Patle, SS Shukla, Ankit Bharti and GK Rana
}

DOI: https://doi.org/10.22271/chemi.2020.v8.i2ak.9112

\begin{abstract}
Study was conducted which title is "Evaluation of different varieties of paddy for production of flaked rice" to evaluate and flaking characteristics of 4 different paddy varieties from the Department of Plant Breeding and Genetics, JNKVV Jabalpur, M.P. The moisture content of paddy varieties varied from 11.38 to $11.99 \%$ (wb). Average length, width, thickness, geometric mean diameter, aspect ratio, porosity, true density, bulk density and coefficient of friction were measured. All varieties had different dimensions, the average length varied from 8.50 to $9.90 \mathrm{~mm}$, average width varied from 2.02 to $3.15 \mathrm{~mm}$, Average test weight varied from 26.06 to $31.21 \mathrm{~g}$, Bulk density and true density varied from 0.58 to 0.68 $\mathrm{g} / \mathrm{ml}$ and 1.12 to $1.45 \mathrm{~g} / \mathrm{ml}$, Angle of repose 29.34 to 32.45 respectively. The flaking characteristic was found average for different flaking parameters and best flaking was obtain by the JR- 81 and Kranti varieties. It was found that moisture content, fat content, protein content was decreased and ash content was increased after processing of flaked rice. Above mentioned data showed that variety JR-81, Kranti, MTU- 1010 and IR- 64 were found best for flaked rice. Sensory quality of flaked rice was observed best quality flaked rice of JR-81 variety followed by kranti, MTU-1010 and IR-64. The physical characteristics of the rice varieties varied with higher the bulk density for Kranti and variety, which had good flaking characteristics for preparation of flaked rice. Minimum protein content of variety was observed in JR-81 and IR-64, which could be the reason for better flaking quality. Higher flaking characteristics were observed for each variety at $150-160{ }^{\circ} \mathrm{C}$ roasting temperature. flaking yield was found to be higher for JR-81 and kranti variety and was also given higher sensory score. The amylose content of kranti had similar characteristics as JR-81 and was rated high in sensory acceptability. Hence, kranti can be recommended for flaking purposes.
\end{abstract}

Keywords: Flaked rice, roasting, amylose content, sensory score, soaking time

\section{Introduction}

Rice (Oryza sativa L.) is the most important and extensively grown food crop in the world and the staple food of more than 60 percent of the world population. Global paddy production in 2016-17 is 751.9 million tonnes (499.2 million tonnes, milled basis) and Asian countries produces record of 680.1 million tonnes (451.4 million tonnes, milled basis) in 2016 (Rice Market Monitor, 2017) ${ }^{[26]}$. India has the largest area under paddy cultivation in the world and ranks second in the production after China. The total production of rice in Madhya Pradesh state during 2015-16 was 6.09 million tonnes. (Agricultural Statistics at a Glance 2016) ${ }^{[3]}$.

Rice is primarily a high calorie food. The major part of rice consists of carbohydrate in the form of starch, which is about 72- 75 percent of the total grain composition and the protein content of rice is around 7 percent.

The rice production, processing and marketing constitute the biggest industry in the country. It has been estimated that about 10 percent of total rice production is utilized for production of flaked rice, expanded rice and popped rice (Sulochana et al., 2007) ${ }^{[31]}$. The common dishes made with it are onion poha and potato poha. The roasted thick -flaked rice called chiwda or chura is used in namkins, which are fried crispy snack made with the mixture of cereals and pulses. The flaked rice is easily digestible and serves as nutritionally rich traditional food item with improved nutritional attributes.

Rice flakes or poha is an important breakfast in semi-urban and rural areas and middle-class families of urban India. Spicy or sweet preparations made from it are not only easy to make but they can be made at a short notice as well. Therefore, it is extensively used all over the country round the year. 
Apart from households, its spicy preparations are also sold in restaurants, roadside dhabas or eateries, and canteens etc. In states, where it is consumed as breakfast, there is more production and larger industries exist. Flaked Rice (Poha) industries are located in different states of the country are. Karnataka, Gujarat, Madhya Pradesh and Chhattisgarh In other states, production is only at a cottage level (Sulochana et al., 2007) ${ }^{[31]}$.

\section{Materials and Methods \\ Materials}

This chapter deals with the various experimental technique materials and methodologies used for evaluation of different varieties of paddy for production of flaked rice (Poha). The present investigation was carried out in the Department of Food science and Technology, JNKVV Jabalpur (MP) during the year 2018-19) and Shree Sharda Industries waraseoni Balaghat (MP).

The breeder seed $(5 \mathrm{~kg})$ of 4 varieties namely Kranti, JR-81, MTU-1010 and IR-64 were used in the investigation. The sample materials were properly cleaned, graded and then properly packed in cloth bags and stored at ambient condition for further use in experiments.

Method: Physical properties of different genotypes of paddyTest weight- 1000 grain weighed of different genotypes of paddy was determined by counting grains and recording their weight using digital weighing balance with an accuracy of $0.001 \mathrm{~g}$. The average value of 3 replications was recorded. Dimensions (length, width and thickness)- 100 grains were randomly selected and their three principle dimensions (length, width and thickness) were measured using a Vernier calliper to an accuracy of $0.01 \mathrm{~cm}$. length (L) is defined as the distance from the tip cap to the kernel crown, width (W) is defined as the widest point to point measurement taken parallel to the face of the kernel, thickness ( $T$ ) is defined as the distance between the two kernel faces. Bulk density-Bulk density is the ratio of sample weight to its total volume; it was determined by filling a $100 \mathrm{ml}$ graduated cylinder with known quantity of sample. The cylinder was gradually tapped few times and recorded for its volume (Mohsenin, 1970) ${ }^{[23]}$. True density-True density was determined by adding $10 \mathrm{~g}$ of paddy grains in $20 \mathrm{ml}$ toluene in $100 \mathrm{ml}$ measuring cylinder. The final volume was noted and true volume of paddy sample was determined from the difference. The true density of the sample was expressed as the ratio of weight of sample and the true volume, g / $\mathrm{ml}^{3}$ (Mohsenin, 1970) ${ }^{[23]}$. Angle of repose $(\theta)$-The angle of repose for the grain was determined by the method suggested by Waziri and Mettal (1983) ${ }^{[36]}$. The geometric mean diameter - The geometric mean diameter also known as the equivalent diameter of rice sample was determined by Mohsenin, 1970 [23]; Sahay and Singh, 2007 ${ }^{[28]}$. Aspect ratio - Aspect ratio is the ratio of width to length of grains, which was determined by using this expression (Varnamkhasti et al., 2008) ${ }^{[32]}$ : The sphericity $(\phi)$ - The sphericity expresses the characteristics shape of a solid object relative to that of a sphere of the same volume and defined as the ratio or the surface area of the sphere having the same volume as that of the grain to the surface of the grain, was determined as (Mohsenin, 1986). Surface area - The surface area (Sa) was calculated using the relationship given by McCabe et al. (1986) ${ }^{[20]}$. Water absorption index and water solubility index - WAI and WSI of rice flour samples were determined following the method described by Kadan et al., $2008^{[15]}$. Swelling power (SP) - SP of flour of rice flake samples was determined by measuring water uptake of the samples (Schoch, 1964). Proximate composition of paddy cultivars - The moisture content The protein content in sample was determined by using conventional micro-Kjeldahl digestion and distillation and fat content in the sample was estimated according to the method of AOAC (1984) ${ }^{[2]}$. Chemical composition of paddy varieties - Starch is composed of two components, namely amylose and amylopectin. (Sadasivam and Manickam, 2005) ${ }^{[27]}$. Sensory Evaluation - A semi trained panel of 10 members was given samples of prepared product of flaked rice (Poha) to evaluate the following sensory quality attributes viz., colour, flavor, taste, texture and over all acceptability score. A nine-point hedonic rating scale score card was used as described in AACC (1967). Statistical Analysis - The skeleton of ANOVA for complete randomized design (CRD) is presented in table given below: (Cyprien and Kumar, 2012) ${ }^{[10]}$

Optimization of conditions for preparation of Flaked Rice The flaked rice of different varieties of paddy was prepared at poha mill unit consists of sand roaster, edge runner flaking machine, roller flaking machine, and cleaning unit. The raw paddy was soaked in the water at predetermined conditions of soaking time of 12,16 and $24 \mathrm{hr}$ at room temperature followed by complete removal of water from soaking tank and allow to reach its moisture content up to $25-28 \%$. The soaked paddy samples S1, S2 and S3 respectively fed manually through stairs into the hopper of paddy roaster. The paddy roaster was operated at the three different temperatures, firstly $\mathrm{T} 1\left(140-150{ }^{\circ} \mathrm{C}\right) \mathrm{T} 2\left(150-160{ }^{\circ} \mathrm{C}\right)$ and $\mathrm{T} 3\left(160-170{ }^{\circ} \mathrm{C}\right)$. After roasting, the resulted moisture content in roasted paddy lies in the range of $17-20 \%$. The roasted paddy was transferred in to edge runner and pressed for 60-65 seconds to make thick flaked rice. The flaked rice (Poha) was further cleaned in a cleaning unit to separate any broken and husk from flaked rice. For making thin flaked rice roasted paddy should be pressed in edge runner machine only for 35-40 seconds and then after cleaned it should be further flattened roller flaker machine for few seconds. The flaked rice was packed in polythene bags and stored in cool and dry places.

Table 1: Experimental plan to study effect of different soaking time and roasting temperature for production of flaked rice.

\begin{tabular}{|r|c|c|c|}
\hline $\begin{array}{r}\text { S. } \\
\text { No. }\end{array}$ & Treatments & Combination & Treatment Description \\
\hline 1. & $\mathrm{~T}_{1}$ & $\mathrm{~S}_{1} \mathrm{~T}_{1}$ & $12 \mathrm{hr}$ Soaking time and $140-150{ }^{\circ} \mathrm{C}$ \\
\hline 2. & $\mathrm{~T}_{2}$ & $\mathrm{~S}_{1} \mathrm{~T}_{2}$ & $12 \mathrm{hr}$ Soaking time and $150-160{ }^{\circ} \mathrm{C}$ \\
\hline 3. & $\mathrm{~T}_{3}$ & $\mathrm{~S}_{1} \mathrm{~T}_{3}$ & $12 \mathrm{hr}$ Soaking time and $160-170{ }^{\circ} \mathrm{C}$ \\
\hline 4. & $\mathrm{~T}_{4}$ & $\mathrm{~S}_{2} \mathrm{~T}_{1}$ & $16 \mathrm{hr}$ Soaking time and $140-150{ }^{\circ} \mathrm{C}$ \\
\hline 5. & $\mathrm{~T}_{5}$ & $\mathrm{~S}_{2} \mathrm{~T}_{2}$ & $16 \mathrm{hr}$ Soaking time and $150-160{ }^{\circ} \mathrm{C}$ \\
\hline 6. & $\mathrm{~T}_{6}$ & $\mathrm{~S}_{2} \mathrm{~T}_{3}$ & $16 \mathrm{hr}$ Soaking time and $160-170{ }^{\circ} \mathrm{C}$ \\
\hline 7. & $\mathrm{~T}_{7}$ & $\mathrm{~S}_{3} \mathrm{~T}_{1}$ & $24 \mathrm{hr}$ Soaking time and $140-150{ }^{\circ} \mathrm{C}$ \\
\hline 8. & $\mathrm{~T}_{8}$ & $\mathrm{~S}_{3} \mathrm{~T}_{2}$ & $24 \mathrm{hr}$ Soaking time and $150-160^{\circ} \mathrm{C}$ \\
\hline 9. & $\mathrm{~T}_{9}$ & $\mathrm{~S}_{3} \mathrm{~T}_{3}$ & $24 \mathrm{hr}$ Soaking time and $160-170{ }^{\circ} \mathrm{C}$ \\
\hline
\end{tabular}

\section{Results \& Discussion}

The present investigation was planned to evaluate varieties of paddy (Oriza sativa) and their utilization for production of flaked rice (Poha). Various physical properties of paddy and flaked rice viz legth, breadth, test weight, bulk density, true density, angle of repose, geometric mean diameter, aspect ratio, sphericity, surface area, flaked rice recovery, broken percentage of flaked rice were considered as chief criteria of determination. The sensory evaluation of flaked rice (poha) was conducted to evaluate varietal variation in quality 
attributes. The findings obtained during the course of investigation are presented as under.

\section{Physical properties of different varieties of paddy}

A perusal of (Table 2) indicates that mean values of length and breadth ranged from 8.50 to 9.90 and 2.02 to $3.15 \mathrm{~mm}$. The statistical analysis indicated a significant variation in the length and breadth of varieties.

A cursory view of (Table 2) indicates that 1000-seed weight (test weight) bulk density and true density of paddy cultivars ranged from 26.06 to $31.21 \mathrm{~g}, 0.58-0.68$ and $1.12-1.45$ respectively. The results show significant difference among the cultivars for above parameters.

The angle of repose of four paddy varieties of paddy varied from 29.34-31.12 was also reported by Ghasemi et al. (2007) [13], Ashtiani et al. (2010) [6], Zareiforoush et al. (2011) [37] and Varnamkhasti et al. (2009) reported the physical properties of raw paddy.

Table 2: Physical properties (Length, Breadth Test weight, Bulk density, True density and Angle of repose) of different varieties of paddy

\begin{tabular}{|c|c|c|c|c|c|c|c|}
\hline S. No. & Varieties & $\begin{array}{c}\text { Length } \\
(\mathbf{m m})\end{array}$ & $\begin{array}{c}\text { Breadth } \\
(\mathbf{m m})\end{array}$ & $\begin{array}{c}\text { Test weight } \\
(\mathbf{g})\end{array}$ & $\begin{array}{c}\text { Bulk density } \\
(\mathbf{g m} / \mathbf{m l})\end{array}$ & $\begin{array}{c}\text { True density } \\
(\mathbf{g m} / \mathbf{m l 3})\end{array}$ & Angle of repose \\
\hline 1. & KRANTI & 9.85 & 3.15 & 31.21 & 0.66 & 1.45 & 31.12 \\
\hline 2. & JR-81 & 9.40 & 2.20 & 27.57 & 0.59 & 1.17 & 30.41 \\
\hline 3. & MTU-1010 & 9.42 & 2.33 & 26.86 & 0.67 & 1.13 & 29.34 \\
\hline 4. & IR-64 & 9.42 & 2.06 & 26.42 & 0.58 & 1.33 & 30.79 \\
\hline & C.D.@5\% & 0.24 & 0.25 & 0.08 & 0.08 & 0.26 & 3.30 \\
\cline { 2 - 7 } & SE(m) \pm & 0.08 & 0.087 & 0.029 & 0.03 & 0.09 & 1.10 \\
\hline
\end{tabular}

Chemical composition and Functional properties of paddy varieties.

The results of starch, amylose and amypectine content in different varieties of paddy are presented in (Table 3) depicted through among four varieties under investigation starch, amylose and amylopectin content varies from 71.97 to $76.61,20.13$ to 25.06 and $74.93-79.86$ percent. The findings reveal that the cultivars belong to group of high starch and high amylopectin content. The findings of investigation are supported with the reported values of Bhattacharya et al. (2004) and joshi et al. (2014) ${ }^{[14]}$.

A perusal of (Table 3) shows that Water absorbing index, Water solubility index and Swelling power of rice. It varied from 4.66 to $5.02,0.98$ to 1.10 and 4.20 to 5.05 respectively. The property greatly influences cooking quality of rice and flaking quality of paddy. The similar findings of above attributes were also reported by kumar et al. (2016) ${ }^{[17]}$ and Ali and Mujoo (2000) ${ }^{[4]}$.

Table 3: Chemical composition of paddy varieties used for production of flaked rice'

\begin{tabular}{|c|c|c|c|c|c|c|c|}
\hline S. No. & Varieties & Starch (\%) & Amylose (\%) & Amylopectin (\%) & WAI & WSI & SP \\
\hline 1. & KRANTI & 76.61 & 25.06 & 74.93 & 4.65 & 1.03 & 4.73 \\
\hline 2. & JR-81 & 73.52 & 20.13 & 79.86 & 4.66 & 1.00 & 4.45 \\
\hline 3. & MTU-1010 & 72.64 & 24.30 & 75.70 & 4.76 & 1.10 & 4.20 \\
\hline 4. & IR-64 & 71.97 & 24.87 & 75.12 & 5.02 & 0.98 & 5.05 \\
\hline & C.D.@\%5 & 2.314 & 2.683 & 2.683 & 0.38 & 0.09 & 0.46 \\
\hline & SE(m) \pm & 0.743 & 0.861 & 0.861 & 0.19 & 0.03 & 0.21 \\
\hline
\end{tabular}

*WAI - water absorbing index

*WSI - water solubing index

*SP- swelling power

\section{Proximate composition of paddy cultivars}

A cursory view of results of proximate composition (Table 4) informs that Moisture, Protein, Fat, Crude fibre and Ash content in paddy cultivars varied from 11.10 to $12.15,6.03$ to $7.09,0.95$ to $1.32,2.77$ to 3.52 and 0.44 to 0.50 , percent respectively. The varietal variation in nutritional composition helps in selecting nutririch paddy cultivars. The present findings can be supported with the reports of Kumar and Prasad (2016) ${ }^{[17]}$.

Table 4: Proximate composition of paddy varieties used for production of flaked rice

\begin{tabular}{|c|c|c|c|c|c|c|}
\hline S. No. & Varieties & Moisture (\%) & Protein (\%) & Fat (\%) & Fiber (\%) & Ash (\%) \\
\hline 1. & KRANTI & 12.15 & 6.71 & 1.32 & 3.52 & 0.49 \\
\hline 2. & JR-81 & 11.10 & 7.09 & 0.98 & 2.92 & 0.50 \\
\hline 3. & MTU-1010 & 12.01 & 6.23 & 0.95 & 2.77 & 0.44 \\
\hline 4. & IR-64 & 11.86 & 6.03 & 0.98 & 3.22 & 0.48 \\
\hline \multirow{2}{*}{} & C.D.@5\% & 0.73 & 0.56 & 0.15 & 0.48 & 0.22 \\
\cline { 2 - 7 } & SE(m) \pm & 0.23 & 0.19 & 0.07 & 0.15 & 0.07 \\
\hline
\end{tabular}

Change in moisture content in paddy varieties during processing in to flaked rice

For production of flaked rice, the paddy samples were soaked in water. The moisture content at different stages during production of flaked rice is presented in Table 5 The initial moisture content in paddy samples varied from 11.10 to 12.01 percent. The overnight soaking of paddy causes the increase in moisture content from 25.82 to 28.77 percent. The paddy 
samples after roasting in roster machine, causes the reduction in moisture content. The moisture content in roasted paddy varied from 17.02-17.41 percent. The roasted paddy when transferred to edge runner for production of flaked rice also causes reduction in moisture content. The moisture content in flaked rice was found to varied from $6.61-7.43$ percent.

Table 5: Moisture content in paddy varieties at different processing stages of production of flaked rice

\begin{tabular}{|c|c|c|c|c|c|}
\hline S. No. & Varieties & $\begin{array}{c}\text { Initial moisture } \\
\text { content (\%) }\end{array}$ & $\begin{array}{c}\text { Moisture content in } \\
\text { Soaked Paddy (\%) }\end{array}$ & $\begin{array}{c}\text { Moisture content in } \\
\text { Paddy After Roasting (\%) })\end{array}$ & $\begin{array}{c}\text { Moisture content in } \\
\text { flaked Rice (\%) }\end{array}$ \\
\hline 1. & Kranti & 11.47 & 28.77 & 17.41 & 6.90 \\
\hline 2. & Jr-81 & 11.10 & 25.82 & 17.17 & 6.61 \\
\hline 3. & Mtu-1010 & 12.01 & 27.82 & 17.14 & 7.43 \\
\hline 4. & Ir-64 & 11.86 & 26.86 & 17.02 & 7.19 \\
\hline & C.D. @ 5\% & 0.553 & - & 0.211 & - \\
\cline { 2 - 6 } & SE(m) \pm & 0.167 & 1.118 & 0.064 & 0.200 \\
\hline
\end{tabular}

Effect of different soaking time and roasting temperature on Physical properties of flaked rice.

Table 5 comprises the results effect of soaking time and temperature on Length, Width, Thickness and geometric mean diameter of flaked rice of flaked rice of four different varieties viz. Kranti, JR-81, MTU-1010 and IR-64 of paddy. It varies length from 10.46 to $12.13,8.89$ to $9.98,9.04$ to 9.98 and 8.34 to $9.71 \mathrm{~mm}$ respectively. Width varies from 5.05 to $6.01,4.0$ to $4.42,4.22$ to 4.87 and 3.87 to $4.89 \mathrm{~mm}$ respectively. Thickness varies from 0.56 to $0.63,0.6$ to 0.93 , 0.59 to 0.84 and 0.64 to $0.83 \mathrm{~mm}$ respectively and geometric mean diameter varies from 3.21 to $3.59,3.00$ to $3.62,2.69$ to 3.36 and 2.30 to $3.43 \mathrm{~mm}$ respectively. The present findings can be supported with the reports of Ekanayak and Narasimha (1997) ${ }^{[12]}$ and Vengaiah et al. (2015) ${ }^{[35]}$.

\section{Aspect ratio, Sphericity and Surface area of flaked rice}

Table 4.5 indicates that the results effect of soaking time and temperature on Aspect ratio, sphericity and surface area of flaked rice of four different varieties of paddy, viz. Kranti, JR-81, MTU-1010 and IR-64 of paddy. Aspect ratio varies from 35.51 to $45.14,32.74$ to $43.03,36.89$ to 48.03 and 39.90 to 49.66 respectively. sphericity varies from 29.47 to 33.82 , 32.74 to $43.01,26.95$ to 32.80 and 30.03 to 32.26 respectively. And surface area varies from 32.53 to 41.76 , 33.99 to 38.79 and 25.18 to $37.05 \mathrm{~mm}$ respectively. The findings of present investigation are in conformity with the reported results of Reddy and Chakraverty (2004) ${ }^{[25]}$ and kumar and Prasad (2016) ${ }^{[17]}$.

\section{Bulk density and True density of flaked rice}

Table 4.5 presents the results effect of soaking time and temperature on bulk density and true density of flaked rice of four different varieties of paddy. viz. Kranti, JR-81, MTU1010 and IR-64 of paddy. Bulk density varies from 0.66 to $0.71,0.60$ to $0.67,0.64$ to 0.75 and 0.64 to $0.75 \mathrm{gm} / \mathrm{ml}^{3}$ respectively. The findings of bulk density and true density of flaked rice can be substantiated with reported results of Chitra et al. (2009) and Mohapatra and Bal. (2012).

Effect of different Soaking time and roasting temperature on Starch, amylose and amylopectin of Flaked Rice

Table 4.6 comprises the results effect of soaking time and temperature on starch, amylose and amylose of four different varieties of paddy. viz. Kranti, JR-81, MTU-1010 and IR-64 of paddy. starch varies from 72.43 to $76.18,68.45$ to 75.62 , 70.81 to 74.40 and 70.95 to 73.36 percent respectively. The amylose content ranges from 22.36 to $26.44,19.87$ to 24.64 , 19.91 to 25.46 and 22.24 to 26.16 percent respectively. And amylopectin from 73.56 to $77.63,75.36$ to $80.13,74.54$ to 80.09 and 73.83 to 77.76 percent respectively. The findings of present investigation are in conformity with the reported results of Bhattacharyya et al. (2004) and Oko et al. (2012) [24].

Flaked rice recovery attributes Total flaked rice, Flaked rice recovery and Broken percentage

Table 4.6 indicates that the results effect of soaking time and temperature on Total flaked rice, Flaked rice recovery and Broken percentage of flaked rice of four different varieties viz. Kranti, JR-81, MTU-1010 and IR-64 of paddy. The total flaked rice varies from 66.05 to $69.63,64.51$ to $68.69,63.56$ 68.85 and $62.98-67.73$ percent respectively. The flaked rice recovery varies from a value of 60.30 to $65.45,58.44$ to $64.57,57.49$ to 64.61 and 56.86 to 63.21 percent respectively and the broken percentage varies from 4.12 to $6.11,4.23$ to $6.07,4.23$ to 6.18 and 4.52 to 6.12 percent respectively. The findings of present investigation are in conformity with the reported results of Bandara et al. (2007) ${ }^{[7]}$ and Shankara et al. $(1984)^{[30]}$.

\section{Sensory Evaluation of Flaked Rice}

the sensory qualities of four different varieties viz. Kranti, JR-81, MTU-1010 and IR-64 of paddy. Higher in kranti paddy variety for thick sized flaked rice as compare to other variety hence the texture of flaked rice of kranti was best. The higher score for all attributes were given to kranti (7.11 to 8.02) (the $T_{5}$ treatment got the best overall acceptability among all 9 treatments) followed by JR-81 (7.17 to 7.88), (the $\mathrm{T}_{5}$ treatment got the best overall acceptability among all 9 treatments), MTU-1010(7.30 to 7.75) (the $\mathrm{T}_{4}$ treatment got the best overall acceptability among all 9 treatments) and IR64 (7.21 to 7.81) (the $\mathrm{T}_{3}$ treatment got the best overall acceptability among all 9 treatments) respectively. The findings of present investigation are in conformity with the reported results of Anitha and Rajalakshmi. (2012) ${ }^{[5]}$. 
Table 6: Effect of different soaking time and roasting temperature on Aspect ratio, Sphericity, Surface area, Bulk density and True density of flaked rice

\begin{tabular}{|c|c|c|c|c|c|c|c|}
\hline S. No & Varieties & Treatment & Aspect ratio & Sphericity & Surface Area $\left(\mathrm{mm}^{2}\right)$ & BD $\left(\mathrm{g} / \mathrm{ml}^{3}\right)$ & TD $\left(\mathrm{g} / \mathrm{ml}^{3}\right)$ \\
\hline \multirow{11}{*}{1.} & \multirow{11}{*}{ Kranti } & $\mathrm{T}_{1}$ & 45.14 & 29.47 & 37.79 & 0.71 & 1.65 \\
\hline & & $\mathrm{T}_{2}$ & 42.85 & 32.36 & 40.48 & 0.7 & 1.66 \\
\hline & & $\mathrm{T}_{3}$ & 41.37 & 33.73 & 37.44 & 0.67 & 1.67 \\
\hline & & $\mathrm{T}_{4}$ & 40.37 & 33.77 & 32.53 & 0.67 & 1.64 \\
\hline & & $\mathrm{T}_{5}$ & 35.80 & 33.78 & 41.76 & 0.71 & 1.64 \\
\hline & & $\mathrm{T}_{6}$ & 41.73 & 33.66 & 39.27 & 0.66 & 1.65 \\
\hline & & $\mathrm{T}_{7}$ & 40.55 & 33.16 & 39.25 & 0.68 & 1.66 \\
\hline & & $\mathrm{T}_{8}$ & 35.51 & 33.82 & 36.01 & 0.67 & 1.67 \\
\hline & & $\mathrm{T}_{9}$ & 36.10 & 33.43 & 39.40 & 0.7 & 1.65 \\
\hline & & C.D.@5\% & 0.19 & 0.09 & 0.06 & 0.04 & 0.04 \\
\hline & & $\mathrm{SE}(\mathrm{m}) \pm$ & 0.06 & 0.03 & 0.02 & 0.01 & 0.01 \\
\hline \multirow{11}{*}{2.} & \multirow{11}{*}{ JR-81 } & $\mathrm{T}_{1}$ & 38.68 & 32.29 & 35.01 & 0.64 & 1.52 \\
\hline & & $\mathrm{T}_{2}$ & 43.01 & 29.33 & 34.27 & 0.65 & 1.47 \\
\hline & & $\mathrm{T}_{3}$ & 40.59 & 30.21 & 33.99 & 0.67 & 1.49 \\
\hline & & $\mathrm{T}_{4}$ & 33.64 & 31.56 & 38.77 & 0.6 & 1.53 \\
\hline & & $\mathrm{T}_{5}$ & 33.07 & 32.14 & 38.79 & 0.61 & 1.55 \\
\hline & & $\mathrm{T}_{6}$ & 36.38 & 29.71 & 35.88 & 0.65 & 1.52 \\
\hline & & $\mathrm{T}_{7}$ & 32.74 & 31.06 & 38.20 & 0.66 & 1.6 \\
\hline & & $\mathrm{T}_{8}$ & 34.76 & 30.17 & 38.78 & 0.64 & 1.63 \\
\hline & & $\mathrm{T}_{9}$ & 37.04 & 31.09 & 38.52 & 0.63 & 1.62 \\
\hline & & C.D.@5\% & 0.08 & 0.08 & 0.09 & 0.06 & 0.08 \\
\hline & & $\mathrm{SE}(\mathrm{m}) \pm$ & 0.03 & 0.03 & 0.03 & 0.01 & 0.03 \\
\hline \multirow{11}{*}{3.} & \multirow{11}{*}{ MTU-1010 } & $\mathrm{T}_{1}$ & 47.71 & 30.28 & 33.94 & 0.7 & 1.44 \\
\hline & & $\mathrm{T}_{2}$ & 48.00 & 32.39 & 32.40 & 0.72 & 1.51 \\
\hline & & $\mathrm{T}_{3}$ & 38.84 & 31.48 & 35.48 & 0.67 & 1.45 \\
\hline & & $\mathrm{T}_{4}$ & 43.88 & 32.80 & 35.08 & 0.71 & 1.56 \\
\hline & & $\mathrm{T}_{5}$ & 48.03 & 31.58 & 34.27 & 0.64 & 1.5 \\
\hline & & $\mathrm{T}_{6}$ & 40.23 & 29.06 & 29.18 & 0.74 & 1.49 \\
\hline & & $\mathrm{T}_{7}$ & 36.89 & 28.81 & 28.68 & 0.55 & 1.62 \\
\hline & & $\mathrm{T}_{8}$ & 39.88 & 26.95 & 29.72 & 0.68 & 1.46 \\
\hline & & $\mathrm{T}_{9}$ & 39.00 & 28.12 & 29.83 & 0.75 & 1.53 \\
\hline & & C.D.@5\% & 0.87 & 0.89 & 1.91 & 0.04 & 0.04 \\
\hline & & $\mathrm{SE}(\mathrm{m}) \pm$ & 0.29 & 0.30 & 0.64 & 0.01 & 0.01 \\
\hline \multirow{11}{*}{4.} & \multirow{11}{*}{ IR-64 } & $\mathrm{T}_{1}$ & 48.12 & 30.68 & 30.89 & 0.66 & 1.34 \\
\hline & & $\mathrm{T}_{2}$ & 47.38 & 30.92 & 31.58 & 0.56 & 1.43 \\
\hline & & $\mathrm{T}_{3}$ & 39.90 & 31.72 & 33.66 & 0.64 & 1.44 \\
\hline & & $\mathrm{T}_{4}$ & 46.64 & 30.96 & 25.18 & 0.75 & 1.51 \\
\hline & & $\mathrm{T}_{5}$ & 47.42 & 30.03 & 28.81 & 0.7 & 1.56 \\
\hline & & $\mathrm{T}_{6}$ & 49.51 & 30.40 & 32.95 & 0.67 & 1.46 \\
\hline & & $\mathrm{T}_{7}$ & 43.08 & 29.92 & 30.97 & 0.76 & 1.57 \\
\hline & & $\mathrm{T}_{8}$ & 49.66 & 30.58 & 37.05 & 0.78 & 1.37 \\
\hline & & $\mathrm{T}_{9}$ & 47.65 & 32.26 & 34.13 & 0.71 & 1.55 \\
\hline & & C.D.@5\% & 0.43 & 0.66 & 1.43 & 0.04 & 0.03 \\
\hline & & $\mathrm{SE}(\mathrm{m}) \pm$ & 0.14 & 0.22 & 0.48 & 0.01 & 0.01 \\
\hline
\end{tabular}

Table 7: Effect of different soaking time and roasting temperature on yield of total flaked rice, flaked rice recovery and broke percent

\begin{tabular}{|c|c|c|c|c|c|c|c|c|}
\hline $\begin{array}{l}\text { S. } \\
\text { No. }\end{array}$ & Varieties & Treatment & $\begin{array}{c}\text { Total flaked rice } \\
(\%)\end{array}$ & $\begin{array}{c}\text { Flaked Rice recovery } \\
(\%)\end{array}$ & $\begin{array}{c}\text { Broken } \\
(\%)\end{array}$ & $\begin{array}{c}\text { Starch } \\
(\%)\end{array}$ & $\begin{array}{c}\text { Amylose } \\
(\%)\end{array}$ & $\begin{array}{c}\text { Amylopectin } \\
(\%)\end{array}$ \\
\hline \multirow{11}{*}{1.} & \multirow{11}{*}{ Kranti } & $\mathrm{T}_{1}$ & 66.05 & 60.30 & 5.75 & 75.67 & 24.79 & 75.20 \\
\hline & & $\mathrm{T}_{2}$ & 67.01 & 61.98 & 5.03 & 76.18 & 26.44 & 73.56 \\
\hline & & $\mathrm{T}_{3}$ & 67.31 & 62.51 & 4.80 & 76.06 & 25.05 & 74.95 \\
\hline & & $\mathrm{T}_{4}$ & 68.46 & 63.07 & 5.38 & 75.49 & 26.02 & 73.98 \\
\hline & & $\mathrm{T}_{5}$ & 69.63 & 65.45 & 4.17 & 76.11 & 25.66 & 74.33 \\
\hline & & $\mathrm{T}_{6}$ & 69.19 & 63.45 & 5.73 & 75.92 & 24.24 & 75.75 \\
\hline & & $\mathrm{T}_{7}$ & 67.86 & 62.38 & 5.48 & 72.68 & 22.36 & 77.63 \\
\hline & & $\mathrm{T}_{8}$ & 68.95 & 63.24 & 5.70 & 73.43 & 24.12 & 75.87 \\
\hline & & $\mathrm{T}_{9}$ & 67.66 & 61.34 & 6.32 & 74.07 & 25.13 & 74.87 \\
\hline & & C.D.@5\% & 0.34 & 0.35 & 0.34 & N/A & 3.09 & 3.09 \\
\hline & & $\mathrm{SE}(\mathrm{m}) \pm$ & 0.16 & 0.12 & 0.16 & 1.35 & 1.03 & 1.03 \\
\hline \multirow{6}{*}{2.} & \multirow{6}{*}{ JR-81 } & $\mathrm{T}_{1}$ & 64.85 & 59.19 & 5.66 & 75.62 & 23.51 & 76.49 \\
\hline & & $\mathrm{T}_{2}$ & 64.51 & 58.44 & 6.07 & 74.44 & 23.86 & 76.14 \\
\hline & & $\mathrm{T}_{3}$ & 65.83 & 60.38 & 5.45 & 73.26 & 24.06 & 75.94 \\
\hline & & $\mathrm{T}_{4}$ & 67.96 & 63.17 & 4.78 & 72.43 & 24.64 & 75.36 \\
\hline & & $\mathrm{T}_{5}$ & 68.69 & 64.57 & 4.12 & 69.09 & 21.76 & 78.24 \\
\hline & & $\mathrm{T}_{6}$ & 66.82 & 62.31 & 4.51 & 68.45 & 19.87 & 80.13 \\
\hline
\end{tabular}




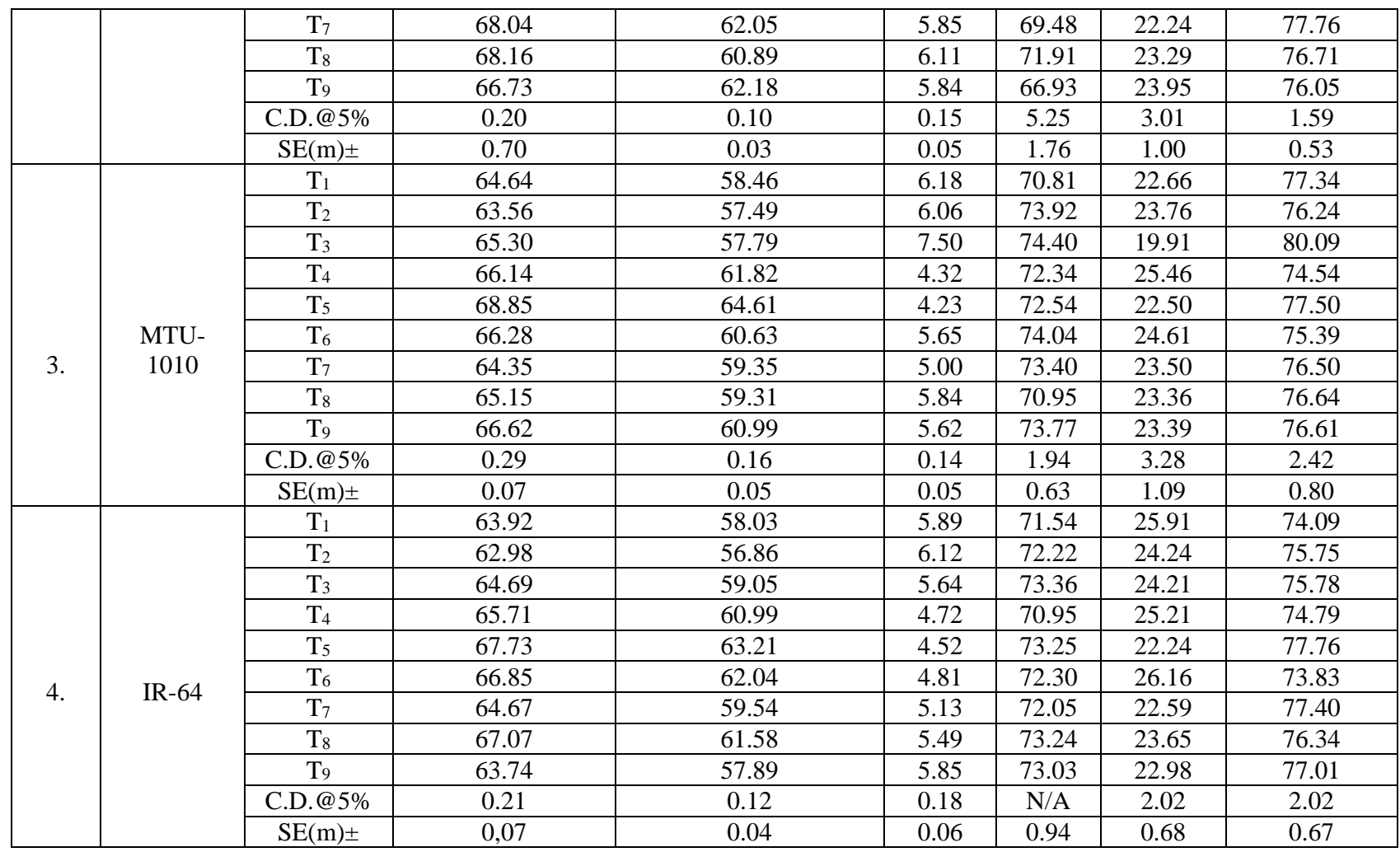

\section{Conclusion}

The effect of soaking and roasting temperature was found to exhibit significant effect on quality of flaked rice. Higher flaking characteristics were observed for each variety at 150$160{ }^{\circ} \mathrm{C}$ roasting temperature. The highest flaked rice recovery was found in kranti variety. The amylose content of kranti variety was similar as JR-81 and was rated high in sensory acceptability. Hence, kranti and JR-81 can be recommended for flaking purposes. Best sensory qualities attributes of flaked rice were observed in JR-81 variety followed by kranti, MTU-1010 and IR-64.

\section{References}

1. AACC. Approved methods of analysis. American Association of Cereal Chemists. St.Paul, Minnesota, USA, 2000.

2. AOAC. Association of Analytical Chemists Standard Official Methods of Analysis of the Association of Analytical Chemists. 14th edition, S.W. Williams (Ed), Washington, DC., 1984, 121.

3. Agriculture Statistics at a Glance, 2016. http://eands.dacnet.nic.in/PDF/Glance-2016.pdf

4. Ali SJ, Mujoo R. Changes in physico chemical and rheological properties of rice during flaking. International Journal of Food Properties. 2000; 3(1):117-135.

5. Anitha G, Rajya Lakshimi P. Value added products with popular low-grade rice varieties of Andhra Pradesh, Journal of Food Science and Technology. 2012; 51(12):3702-3711.

6. Ashatinie AH, Sadeghi M, Hemmat A. Some physical properties of two rough rice varieties as affected by moisture content. 2010; 24:205-20.

7. Bandara D, Bandara B, Wickramanayaka W, Rathnayake H, Senanayake D, Palipane K. Design and Development of A Small /Medium Scale Rice Flaking Machinery for Manufacture of Rice Flakes. Annual Transactions of IESL, 2007, 168-175.
8. Bhattacharya KR. Breakage of rice during milling and effect of parboiling. Cereal Chemistry. 1969; 46(5):592600.

9. Chitra M, Singh V, Ali SZ. Effect of processing of paddy on digestibility of rice starch by in vitro studies. Journal of Food Science Techlnlogy. 2010; 47(4):414-419.

10. Cyprien M, Kumar V. A comparative statistical analysis of rice cultivars data. Journal of Reliability and Statistical Studies. 2012; 5(2):143-161.

11. Daomukda N, Moongngarm A, Payakapol L, Noisuwan A. Effect of Cooking Methods on Physicochemical Properties of Brown Rice. 2011 2nd International Conference on Environmental Science and Technology IPCBEE, IACSIT Press, Singapore, 2011, 6.

12. Ekanayaka S, Narasimha HV. Comparative properties of rice flakes prepared using edge runner and roller flaker. Journal of Food Science and Technology. 1997; 34(4):291-295.

13. Ghasemi VM, Mobli H, Jafari A, Rafiee S, Soltanabadi M, Kheiralipour K. Some engineering properties of paddy (Var. Sazandegi). International Journal of Agriculture and Biology. 2007; 5:763-766.

14. Joshi ND, Mohapatra D, Joshi DC. Varietal selection of some Indica rice for production of puffed rice. Food Bioprocess Technology. 2014; 7:299-305.

15. Kadan RS, Byrant RJ, Miller JA. Effects of milling on functional properties of rice flour. Journal of Food Science. 2008; 73(4):151-154.

16. Kumar S, Prasad K. Optimization of Flaked Rice Dry Roasting in Common Salt and studies on associated changes in chemical, Nutritional, Optical, Physical, Rheological and Textural Attributes. Asian Journal of Chemistry. 2017; 29(6):1380-1392.

17. Kumar S, Haq R, Prasad K. Studies on physico-chemical, functional, pasting and morohological characteristics of developed extra thin flaked rice. Journal of Saudi Society of Agricultural Sciences, 2016.

18. Kumar S, Prasad K, Shekhar S. Temperature dependent roasting kinetics change in opto-physical and textural 
characteristics of flaked rice. Production and processing of food crop for value addition: technlgy and genetics option, agrobios (international), 2017.

19. Kumar S, Prasad K, Singh Yadav Y. Physical Properties of Paddy as Affected During Transformation to Flaked Rice. Production and processing of Food Crops for Value Addition: Technology and Genetics Options, Agrobios (International). 2013, 211-214.

20. McCabe WL, Smith JC, Harriott P. Unit Operations of Chemical Eng. McGraw-Hill, New York, 1986.

21. Mohapatra NN. Physical properties of plant and animal materials Physical characteristics and mechanical properties. Gordon and Breach Science publishers, New York. 1970, 1.

22. Mohsenin NN. Physical properties of plant and animals, 1st edition, New York Gordon and Breach Science Publishers Inc: 1980, 73-75

23. Mohsenin NN. Physical Properties of Plant and Animal Materials. 1st Edn., Gordon and Breach Science Publishers, New York, USA, 1970.

24. Oko AO, Ubi BE, Dambaba N. Rice Cooking Quality and Physico Chemical Characteristics: A Comparative Analysis of Selected Local and Newly Introduced Rice Varieties in Ebonyi State, Nigeria. Food and Public Health. 2012; 2(1): 43-49.

25. Reddy BS, Chakraverty A. Physical properties of raw and parboiled paddy. Biosystems Engineering. 2004; 88(4):461-466.

26. Rice market monitor 2017 EST: Rice Market Monitor (RMM) - FAO (www.fao.org)

27. Sadasivam S, Manickam A. Biochemical Methods. New Age International, 2005.

28. Sahay KM, Singh KK. Unit Operations of Agricultural Processing. Vikas Publishing House, New Delhi, 2007.

29. Schoch TJ. Methods in Carbohydrate Chemistry Academic Press: New York, 1964, 106-108.

30. Shankara R, Ananthchar TK, Narsimha HV, Krishnamurty H, Desikachar HSR. Journal of Food Science and Technology. 1984; 21(3):121-122.

31. Sulochana S, Singaravadivel K, Vidyalakshmi R, Dakshinamurthy A. A profile of the flaked rice industry in India. Cereal Food World. 2007; 52(5):257- 261.

32. Varnamkhasti MG, Mobli H, Jafari A, Keyhani AR, Soltanabadi MH, Rafiee S et al. Some physical properties of rough rice (Oryza sativa L.) grain. Journal of Cereal Science. 2008; 47(3):496-501.

33. Verma DK, Mohan M, Prabhakar PK, Srivastav PP. Physicochemical and cooking characteristics of Azad basmati. International Food Research Journal 2014; 22(4):1380-1389.

34. Visvanathan R, Palanisamy PT, Gothandapani L, Sreenarayan VV. Physical properties of neem nut. Journal of Agricultural Engineering and Research. 1996; 63:19-26.

35. Vengaiah PC, Vijaya Kumara B, Murthy GN, Prasad KR, Physico-Chemical Properties of Palmyrah fruit Pulp (Borassus abellifer L). J Nutr Food Sci, 2015; 5:391.

36. Waziri AN, Mittal JP. Design related physical properties of selected agricultural products. Agricultural Mechanization in Asia, Africa and Latin America, 1983; 14:59-62

37. Zareiforoush H, Osseinzadeh BH, Adabi ME, Motavali A. Moisture dependent physical properties of paddy grains. Journal of American Science. 2011; 7(7). 